\title{
A Preliminary Review on Economies of Scale (EOS) Towards Industrialized Building System (IBS) Manufacturer
}

\author{
Syazwana Tajul Ariffin ${ }^{1}$, Riduan Yunus ${ }^{1, *}$, Hairuddin Mohammad $^{2}$, and Siti Khalijah \\ Yaman $^{1}$ \\ ${ }^{1}$ Jamilus Research Centre, Faculty of Civil and Environmental Engineering, Universiti Tun Hussein \\ Onn Malaysia, 86400 Batu Pahat, Johor, Malaysia \\ ${ }^{2}$ Faculty of Architecture, Planning, and Survey, Universiti Teknologi MARA, Shah Alam, Selangor, \\ Malaysia
}

\begin{abstract}
Industrialized Building System (IBS) is a potential technology to improve productivity of construction industry. Controlled production and minimum generation of construction waste are some of the benefits that can be achieved by replacing conventional construction with IBS. In business, IBS is giving a huge opportunity for manufacturer and supplier to expand their business while contributing to construction development. However, bad strategies will put the company in high risk due to higher initial capital for machines and equipment. Therefore, strategic planning for company's growth, profit maximization, and enhancement of productivity is undeniable to ensure the success of business in construction industry. This preliminary paper is exploring associated factors that affect Economy of Scale (EOS) and their relationships in catalyzing the IBS manufacturer especially precast concrete as the scope of study to continue their business in the construction industry. Thus, a framework of EOS is proposed to assist IBS manufacturers to ensure their company's growth and stability, competitiveness in term of monopoly or an oligopoly, increasing productivity, leading constant returns to scale, and finally increasing the firm's efficiency. The refined EOS's conceptual framework is an important turning point to support the development of decision making tools for IBS manufacturer towards their stability and survival in this highly competitive industry.
\end{abstract}

\section{Introduction}

The Malaysia government is greatly promoting the implementation of Industrialized Building System (IBS) to enhance productivity in construction industry through the cooperation of Construction Industry Development Board (CIDB), IBS Centre, and Malaysian Investment Development Authority (MIDA). According to Azman [1], IBS has a potential to improve the quality of constructed projects and eliminate problems which normally faced in conventional method such constructability and higher construction cost.

\footnotetext{
"Corresponding author: riduan@uthm.edu.my
} 
The success of IBS implementation depends on the supply chain management. Each phase in IBS implementation, starting from design to maintenance and demolition, needs to be examined carefully to improve the deliveries of IBS projects. This study is focusing on manufacturing process which investigates the EOS of a company in sustaining their business in the construction industry. The numbers of IBS manufacturers are increasing over the years. In 2007, the total registered IBS manufacturer is 128 companies and it is increasing to 201 in 2015 [2]. Within the same vein, those increments are translated to competitive advantage in manufacturing which is essential for the industry to maintain uptrend performances due to attainment of economic sustainability, improved equipment efficiency, and reducing production disturbance, all for amplified productivity [3]. Based on a report published by the Economic Planning Unit of Prime Minister's Department [4], during the Eleventh Malaysia Plan (2016-2020), productivity is focused as renewed effort towards national, industry, and enterprise economy.

On the other hand, there are various factors that contributed to the challenges of Malaysia's construction industry especially in the enhancement of productivity. Prior to that, each of construction projects is unique, thus, there are uncertainties which lead to variation in both the prognosis and the actual economic result [5]. However, following a report from Malaysian Investment Development Authority (MIDA) [2], the adoption of IBS in the construction sector is still low and represents only about 15 to 20 per cent of the overall projects in Malaysia despite being in the industry for around 50 years. This percentage is lower than expected notwithstanding huge publicity campaign from the government. The fragmented and disconnected construction supply chains are major causes of the limited uptake as there are only 205 manufacturers that mostly located in the city areas [6].

Subsequently, the manufacturer is struggling to sustain their business due to nonstandardization and shortage of demand of IBS components [7]. In most cases, builders have different requests in term of components' specifications, which further require the manufacturers to invest for new molds [7]. This scenario is deemed not sustainable as the manufacturing companies usually have their own economic strategic planning. It is because of the trend of mass production which requires the customization of products and services that eventually leading to cost reduction [8]. Therefore, it is posited that holistic manufacturing strategies must be developed in order to ensure that future productions are able to meet this new demand. Additionally, along the way, a firm needs to organize its operational processes in terms of both technical and economic efficiency to survive in the long run [9]. Thus, scale economies are seen as significant savior which are able to lead for growth towards businesses by reducing average costs and simultaneously increasing levels of productivity appropriately [10]. Here, a positive prospect from the understanding of the concept of EOS might benefit the manufacturing organizations despite of their sizes. Therefore, identifying related factors regarding EOS is deemed paramount and will be a useful reference for the IBS manufacturers' practices. Hence, this preliminary study was carried out by extensive review of established literatures including the authors preceding research [11] that discussed on generic EOS for construction contractor. The qualitative undertaking was helped by a series of thematic process in order to assist the authors on appropriate direction for concluding a reliable and valid finding [12, 13]. Throughout the process, EOS is categorized into internal and external factors, and influenced by apposite supporting factors.

\section{Implementation of IBS in Malaysia}

The implementation of IBS in Malaysia is still low. Most of industry players have a negative perception and incapable to implement it due to advanced technology which is 
required in its application [14]. In addition, an emphasis towards contractors' satisfaction level in implementing the IBS is also limited to evaluate subjective performance measurement. Based on comparison of construction costs for the precast wall panels, it was $40 \%$ more expensive compared to the cost of a conventional wall, but it promotes less cost for the site labour from RM59 (conventional) to RM23 (precast) per square meter [15].

Previously, Construction Industry Development Board Malaysia (CIDB) [16], highlighted 13 key issues in adopting IBS in term of consultant, contractor, and manufacturer. Examples of problems faced by IBS manufactures which stated in that article are low demand for IBS components, high cost of import duty for IBS manufacturing equipment, expensive installation machinery, sparse location of IBS manufacturer, and costly transportation for components. In addition, Mao et al. [17] identified 24 risk factors in implementing IBS, namely; high cost pressure without economics scale effect, poor cooperation between multi-interface, inappropriate design codes and standards for industrialized building, lack of management practices and experiences, and lack of quality monitoring mechanism in the process of production are some of the high risk factors existed in the process of implementing industrialized building. Therefore, these issues need to be scrutinised in a holistic way as the effective development of firm organization have to ensure the effective economic decisions that may help in minimizing investment, operating, and maintenance expenditures, besides increasing the revenue, savings, and such other positive gains of the organization [18].

\section{Economies of scale}

Economic of scale exist in several activities in industry. According to Alcorta [19], manufacturing industry was implementing the economies of scale according to product, plant, and firm's dimension. New technologies and de-scaling might give benefit in the level of 'optimal' scales. Scale is a size of output. Economies of scale came with theoretical sense of total cost rises less proportionately than output, and optimal scale occurs at the point where any increase in output no longer reduces but raises unit costs [19]. Economies of scale can be classified into two main types which are internal (within the company) and external, which are relied on the advantages of the other supporting industry as a whole [20, 21, 22].

Pyo and Yang [23] stated that, if the input prices decline as a firm increases its output scale, an economies of scale effect can occur even when there is decreasing or constant returns to scale. Therefore, economies of scale are the relationship of scale of the combination productive factors and quantity of the firm output [24]. A simple economic model is able to develop according to Chamberlinian formulation and modified Dixit Stiglitz to assist the intra and inter industry trade market [25]. According to Pyo \& Yang [23], a firm's cost function (C) can be written as in equation (1). A firm's total costs in year $(t)$, where $F_{t}$ is a function of input prices, $Q_{t}$ as outputs, and $T_{t}$ for technology change. Therefore, a firm may achieve positive scale economies even under the condition of decreasing returns to scale when there is a significant decline of factor prices. Meanwhile, the effect of scale economies which is the change of cost with respect to the change of output, can be expressed as in equation (2). The positive EOS ( $\left(\mathrm{EOS}_{\mathrm{t}}\right)$ will give economies of scale result where negative EOS $\left(-\mathrm{EOS}_{\mathrm{t}}\right)$ show diseconomies of scale of the operative firm.

$$
\mathrm{C}_{\mathrm{t}}=C\left(Q_{t} F_{t} T_{t}\right)
$$




$$
\mathrm{EOS}_{\mathrm{t}}=\left(\frac{1}{d \ln C_{t} / d \ln Q_{t}}\right)
$$

Apart, by referring to Fig. 1, the short run average cost curve (SRAC) is based on a particular set of fixed costs. As the firm grows, its fixed cost change and the curves that are redrawn are further to the right on the graph. From these, a long run average cost (LRAC) curve can be constructed as it has a same characteristic U-shape as the SRAC [26]. As firms increase quantity output, average costs fall until reaching the optimal marginal cost. Since economies of scale is cost advantages obtained due to size, cost per unit of output are generally decreasing with increasing scale as fixed cost are spread out to more units of output [27].

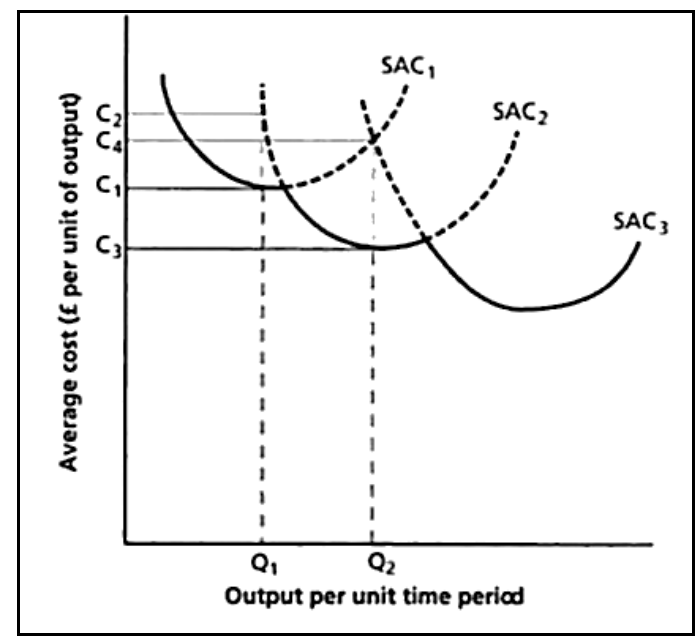

Fig. 1. Economics of scale in short and long run average cost [22].

According to Celli [10][2] that investigates the Small and Medium-Sized (SME) entities familiar with EOS, positive responds were gathered from 59 companies that declared gaining economies of cost by implementing several economies of scale's factors in their productive process. Within organisation, Adam Smith have discussed EOS through division of labour approach, meanwhile Robinson's on economies of massed reserves, management, and large machines [28, 29]. Additionally, internal factors also cover marketing and commercialisation approaches of firm, their workers' specialisation, technical capabilities, and financial portfolios [29, 30]. Meanwhile, from the perspective of external factors, ability of firm to bear business risks, supports to the industry, and supporting infrastructures were some of important determinants to achieve the optimum EOS [22]. Therefore, in order to shed light on each EOS factors, discussions on its impacts towards organisation/firm are paramount, where fair perspectives anchored by appropriate literatures are presented.

There are various impacts of existing EOS in the firm's market. In reality, monopolistic competition is occurred within EOS which in a way faulting fair competitions [31,32]. These competitions contribute in increment of market size. Monopoly's firm that gain profits will eventually attract competitors that lead to oligopoly and further monopolistic competitive [33]. Melvin [34], stated that main features of monopolistic competition in a trade consist of similar goods but differ marketing strategy from the other firm, where subsequently the firm can raise price and gain benefit from marketing power. The 
increasing return to scale may also contributed by the advancement of technology (i.e. through internal factor), however, unfortunately, a firm's entry into trades that may in the long-run contributes to zero profit. This possibly occurs if the industry is gaining profit, it will eventually attract new firms which in the end subsidises lower profits. Economies of scale's impacts can also be observed through the changes of growth in size. However the size of firm is not necessary to obtain economies of cost [9]. In another way, productivity will rise as the size of firm are growing, which contributes by internal and external factors such as having specialized workers and higher technology of machineries [35].

Accordingly, Zhi et al. [36] claimed that economies of scale are able to increase firm's productivity given its potential to influence total factor of productivity (TFP). Therefore, long-term economic growth and comprehensive industry level of productivity measure can be determined by referring to an indicator of economies of scale, which is employed construction output per capita. Since firm's productivity is increased, it may lead to their stability in the long run. Besides, constant returns to scale are achieved when the firm experiencing economies of scale where along the way it will grow further with the increase of profitability [37]. This allows costs to be reduced and contributes rise of production as the returns are constant. On the other hand, exploitation in bargaining power and learning on opportunities to reduce costs are able to gain more businesses [34]. Thus, the impacts towards technical and organizational efficiency are very much related to economic sense which implies profit maximizing behaviour of the firm. Higher efficiency and levels of productivity that showed by larger firm is attainable by higher work intensity and the capital size of firm [37]. Therefore, following the previous discussions [11, 12, 13] based on available literatures, a refined framework in visualising EOS are presented as can be perused in Fig. 2.

\section{Economies of scale and industrialized building system}

IBS approach is not only based on technology solutions, but a holistic process to be implemented [38]. According to Ahmad et al. [39], IBS industry is justified economically when the existing mass production was effectively distributing fixed cost over production of product. In order to achieve economic of scale for manufacturers and buyers, the streamline and standardised IBS component are been highlighted by the CIDB in their IBS Prospectus [40]. In brief, production categories can be divided into craft, mass, and lean production, which came with different operations and outcome as in Table 1. The craft production is known as producing goods with minimal equipment or by hand. Thereafter, mass production is focused on standardised product that is produced in a large scale. Whereby, lean production is a resource utilization towards value and efficiencies of the customer [41,42]. Through preliminary observation, IBS manufacturers in Malaysia are fond towards mass production manufacturing system. These manufacturing systems are able to give advantages in shorter time compared to craft production, where cost reduction and efficiency increment can be enhanced further (i.e. by using economies of scale). Since IBS manufacturing can be improved by economies of scale and automation as it is massbased production, organisation/firm may draw strategic planning of cost minimisation by utilising all resources for producing goods in the market rather than within a firm, which through the end may lead to change of total cost of production [23]. Likewise, by revisiting the issues in Malaysia's IBS manufacturing (see Chapter 2), strengthening the application of EOS towards IBS manufacturing is seen as inevitable in order to achieve construction industry's vision in the recent Construction Industry Transformation Program (CITP) 20162020 (CIDB) [43]. 


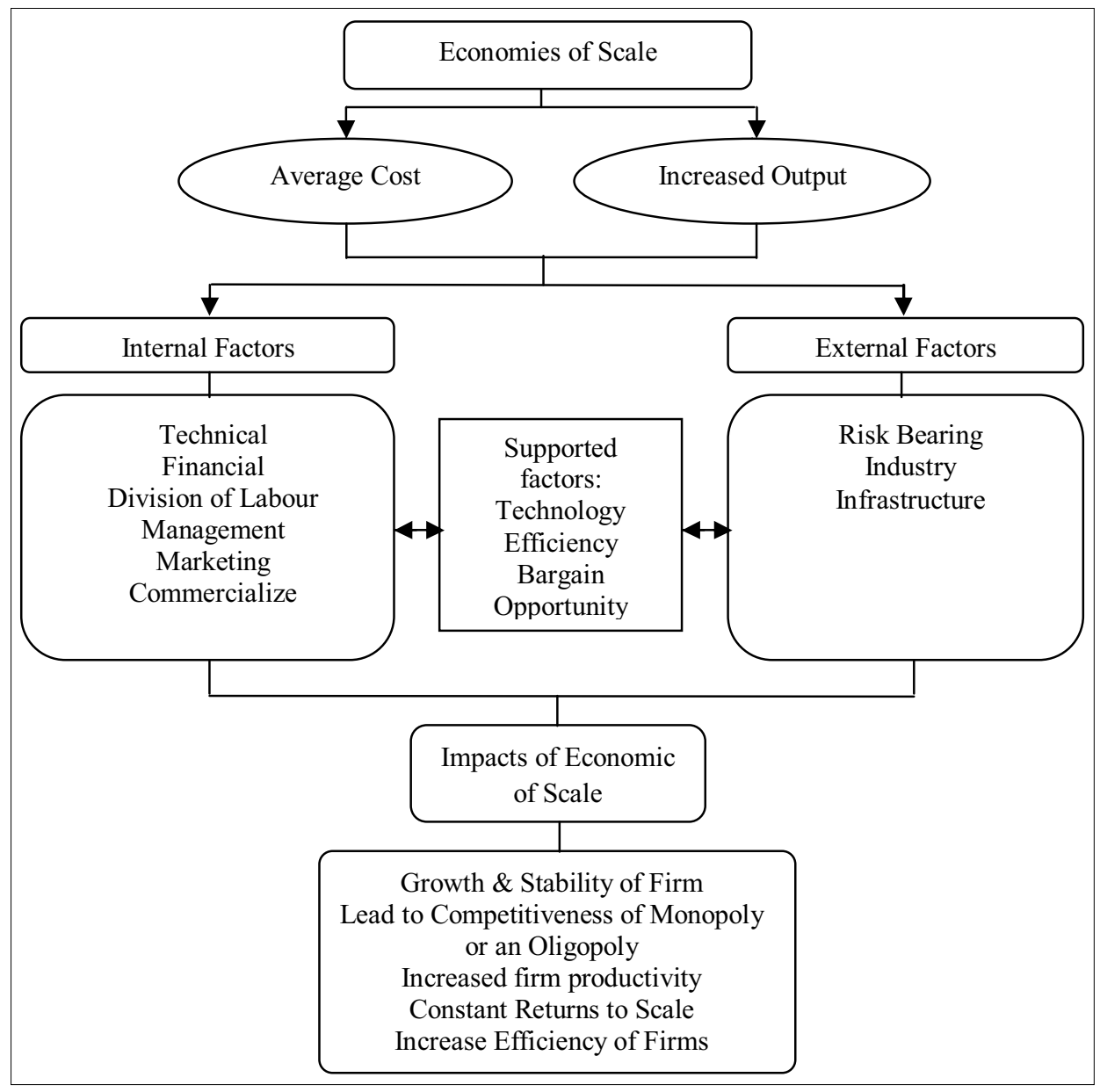

Fig. 2. Refined framework of economies of scale.

Table 1. Categories of production system [42].

\begin{tabular}{|c|c|c|c|}
\hline Functions & Craft Production & Mass Production & Lean Production \\
\hline Focus & Task & Product & Customer \\
\hline Operations & Single Item & Batch and Queue & $\begin{array}{c}\text { Synchronized flow and } \\
\text { pull }\end{array}$ \\
\hline Overall Aim & Mastery of Craft & $\begin{array}{c}\text { Reduce cost and } \\
\text { increase efficiency }\end{array}$ & $\begin{array}{c}\text { Eliminate waste and add } \\
\text { value }\end{array}$ \\
\hline Quality & $\begin{array}{c}\text { Integration (part of } \\
\text { the craft) }\end{array}$ & $\begin{array}{c}\text { Inspection (a second } \\
\text { stage after production) }\end{array}$ & $\begin{array}{c}\text { Prevention (built in by } \\
\text { design and method) }\end{array}$ \\
\hline Business & Customization & $\begin{array}{c}\text { Economies of scale and } \\
\text { automation }\end{array}$ & $\begin{array}{c}\text { Flexibility and } \\
\text { adaptability }\end{array}$ \\
\hline Improvement & $\begin{array}{c}\text { Master-Driven } \\
\text { (continued } \\
\text { improvement) }\end{array}$ & $\begin{array}{c}\text { Expert driven (periodic } \\
\text { improvement) }\end{array}$ & $\begin{array}{c}\text { Workforce driven } \\
\text { (continued } \\
\text { improvement) }\end{array}$ \\
\hline
\end{tabular}




\section{Conclusion and discussion}

In IBS manufacturing, effective strategies will make companies more competitive in the market place, thus creating a lot of spill over effects such as providing employment in particular sector. Unfortunately, the industry was facing a number of shortcomings such as low demand, costly machineries and transportation, location-wise problem, etc. Thus, optimistically, the inclusion of holistic EOS factors (i.e. internal, external, and supports) are expected to counter those deficiencies since given the fact that IBS manufacturing approach is generally adopting mass-based production system, which improvement can be made through EOS. For instances, internal factors of marketing, commercialisation, and financial are very much related to demand and machineries. Whilst, issues on transportation and location might be able to be solved through critical examination of external factors, namely support from surrounding industry and infrastructures.

The impacts from holistic implementation of EOS towards IBS manufacturing firms are very costly to be side-lined. Stability of firm, increasing firm's productivity, and maximising profitability are just some of positive impacts that certainly became objectives of firm's existence. Moreover, following all positive effects will bring (see Figure 2), indirectly, government efforts in nurturing larger uses of IBS components that might be further materialised. Therefore, the authors posit that subsequent research explorations are worth to be taken, where qualitative and quantitative approaches are concerned.

The authors acknowledge and appreciate the financial support provided by the Universiti Tun Hussein Onn Malaysia (UTHM) in Johor, Malaysia through the research university grant.

\section{References}

[1] M.N.A. Azman, M.S.S. Ahamad, and N.D. Hilmi, The perspective view of Malaysian industrialized building system (IBS) under IBS precast manufacturing, 4th Int. Engineering Conf. - Toward Engineering 21st Century, Islamic University of Gaza, $1-13$ (2012)

[2] Malaysian Investment Development Authority (MIDA), Industrialized Building System (IBS) in Malaysia: An Update, MIDA Newsletter Publication for Global Investors, Malaysia, 3, (December, 2015)

[3] A. Ingemansson and G. S. Bolmsjö, Improved efficiency with production disturbance reduction in manufacturing systems based on discrete-event simulation, $\mathrm{J}$. Manufacturing Technology Management, 15,(3), 267-279, (2004)

[4] Economic Planning Unit Prime Minister's Department, Unlocking the potential of productivity, Srategy Paper 1 No. 9431, Economic Planning Unit, Putrajaya, (2009)

[5] G.M. Winch, Towards a theory of construction as production by projects, Build. Res. Inf., 34(2), 154-163, (2006)

[6] Construction Industry Development Board (CIDB), IBS Digest, Industrialised Building System (IBS), Kuala Lumpur, Malaysia, (2016)

[7] Construction Industry Development Board (CIDB), Industrialised Building System (IBS), IBS-Roadmap 2011-2015, Kuala Lumpur Malaysia, (2010)

[8] D.T. Pham, P.T.N. Pham, and A. Thomas, Integrated production machines and systems - beyond lean manufacturing, J. Manufacturing Technology Management, 19(6), 695-711, (2008)

[9] M. Celli, Determinants of economies of scale in large businesses, Am. J. Ind. Bus. Management, 3, 255-261, (2013)

[10] M. Celli, Are EU's Small and medium-sized entities familiar with economies of scale?: Response from the field, World J. Soc. Sci., 5(3), 101-109, (2015) 
[11] S.T. Ariffin, S. Sulaiman, H. Mohammad, S.K. Yaman, and R. Yunus, Factors of Economies of Scale for Construction Contractors, Int. Congress on Technology, Engineering, and Science, Kuala Lumpur, Malaysia, (2016)

[12] S.K. Yaman, A.H. Abdullah, H. Mohammad, and F. Hassan, Technical competency of construction manager in Malaysian construction industry, Applied Mechanics and Materials, 773-774, 1053-1059, (2015)

[13] N. Kariya, Z. Yaakob, M.M. Sairi, H. Mohammad, S. K. Yaman, and N.H. Abas, Investigation of generic house components and their practical ways to be assessed by house buyers during defect liability period in Malaysia, Int. J. Engineering, 29(10), (2016)

[14] R. Yunus, A.N. Masrom, A.H. Abdullah, and F. Mustakim, conceptual model of contractor satisfaction in the industrialized building system ( IBS ) implementation, Applied Mechanics and Materials, 773-774, 828-833, (2015)

[15] T.K. Chan, Mechanisation in construction - A Malaysian perspective, Proc. of the 19th CIB World Building Congress, Brisbane, (2013)

[16] Construction Industry Development Board (CIDB), IBS Digest, Industrialised Building System (IBS), Kuala Lumpur, Malaysia, (2015)

[17] C. Mao, L. Shen, L. Luo, and Z. Li, Identification of Risk Factors Influencing the Implementation of Industrialized Building System in China, Proceedings of the 19th International Symposium on Advancement of Construction Management and Real Estate, 219-230, (2015)

[18] F. Rangelova, Fundamentals of economics in sustainable fundamentals of economics in sustainable construction, Bultest Standard Ltd, Bulgaria, Europe, (2015)

[19] L. Alcorta, The impact of new technologies on scale in manufacturing industries: Issues and evidence, Institute for New Technologies, Netherlands, (1994)

[20] A. Wibowo, The contribution of the construction industry to the economy of Indonesia: A systemic approach, International Seminar CIB 107, UTM, Malaysia, (2009)

[21] E. Henriksen, K.H.M. Knarvik, and F. S. Steen, European manufacturing, London, UK, (2001)

[22] D. Myers, Construction economics: A new approach, First Eds., Spon Press, New York, USA, (2004)

[23] M. Pyo and J. Yang, Optimum allocation between FDI and exporting in the presence of transaction costs and economies of scale: Modeling and examination of MNEs in the automobile industry, $\mathrm{PhD}$ Thesis, The George Washington University, United States, (2008)

[24] G.J. Stigler, The economies of scale, J. Law Economics, 1(1), 54-71, (1958)

[25] P.R. Krugman, Increasing returns, monopolistic competition, and international trade, J. Int. Economics, 9(4), 469-479, (1979)

[26] J. Manser, Economics: A foundation course for the built environment, E\&FN Spoon, London, UK, (1994)

[27] L. Ruddock, Economics for the modern built environment, Taylor and Francis, Oxford, (2009)

[28] C.M. Lindsay and M.T. Maloney, Do rate and volume matter?, Transaction Cost Limits to Economies of Scale, Studies in Economics and Finance, 17(1), 1-14, (1996)

[29] V. Pukelienè and I. Maksvytiené, Economy scale impact on the enterprise competitive advantages, Ekon. mastas ir jo poveikis įmonès konkurenciniams pranašumams., 57(2), 49-54, (2008)

[30] E. Henriksen, K.H.M. Knarvik, and F. Steen, Economies of scale in European manufacturing revisited, Discussion Paper Series No. 2896, Centre for Economic Policy Research, London, United Kingdom, (2001) 
[31] A.D. Chandler, Scale and scope: The dynamics of industrial capitalism, Harvard University Press, Cambridge, USA, (1990)

[32] M.E. Porter, The competitive advantage of nations, Billing and Sons Ltd. Macmillan, Worchester/ London, UK, (1990)

[33] P.R. Krugman and M. Obstfeld, International economics: Theory and policy, Sixth eds., World Student Series, United States of America, (2003)

[34] J. R. Melvin, Increasing returns to scale as a determinant of trade, The Canadian J. Economics, 2(3), 389-402, (1969)

[35] G. A. Carlino, Productivity in Cities: Does City Size Matter?, Business Review, Federal Reserve Bank of Philadelphia, (1987)

[36] M. Zhi, G.B. Hua, S.Q. Wang, and G. Ofori, Total factor productivity growth accounting in the construction industry of Singapore, Construction Management and Economics, 21(7), 707-718, (2003)

[37] F.C. Chia, Economic fluctuations and productivity in the Malaysian construction sector, PhD Thesis, Queensland University of Technology, Queensland, Australia, (2011)

[38] K.A.M. Kamar, Z.A. Hamid, M. Zura, M. Zain, A. Hazim, A. Rahim, M.K. Ghani, M. Nor, A. Azman, T.A. Majid, M. Sanusi, S. Ahamad, and M.N. Azman, Drivers and barriers of industrialised building system (ibs) roadmaps in Malaysia, Malaysian Construction Research J., 9(1), 1985-3807, (2012)

[39] R. Ahmad, M.F. Mohammad, M.F. Musa, and M.R. Yusof, The way forward for industrialised building system IBS, IBS Digest, 23-29, (2015)

[40] Construction Industry Development Board (CIDB), Industrialised Building System (IBS) Roadmap 2011-2015, Kuala Lumpur, Malaysia, (2010)

[41] A. Mossman, Why isn't the UK construction industry going lean with gusto?, Lean Construction J., 24- 36, (2009)

[42] G.F. Jacobs, Review of lean construction conference proceedings and relationship to the Toyota production system framework, PhD Thesis, Colorado State University, Colorado, United State, (2010)

[43] Construction Industry Development Board (CIDB), Construction Industry Transformation Programme (CITP) 2016-2020, Kuala Lumpur, Malaysia, (2015) 